Article

\title{
Antimicrobial Activity of Some Thiourea Derivatives and Their Nickel and Copper Complexes
}

\author{
Hakan Arslan ${ }^{1,2, *}$, Nizami Duran ${ }^{3}$, Gulay Borekci ${ }^{4}$, Cemal Koray Ozer ${ }^{2}$ and Cevdet Akbay ${ }^{1}$ \\ 1 Department of Natural Sciences, Fayetteville State University, Fayetteville, NC 28301, USA; \\ E-mail: cakbay@uncfsu.edu (C. A.) \\ 2 Department of Chemistry, Faculty of Pharmacy, Mersin University, Mersin, TR 33169, Turkey; \\ 3 Department of Microbiology, Faculty of Medicine, Mustafa Kemal University, Hatay, TR 31040, \\ Turkey; E-mail: nizamduran@hotmail.com (N. D.) \\ 4 Health School, Mersin University, Mersin, TR 33169, Turkey; E-mail: gulay_borekci@yahoo.com \\ (G. B.)
}

* Author to whom correspondence should be addressed: E-mails: hakan.arslan.acad@gmail.com; arslanh@mersin.edu.tr; harslan@uncfsu.edu.

Received: 2 December 2008; in revised form: 24 December 2008 / Accepted: 5 January 2009/ Published: 22 January 2009

\begin{abstract}
Five thiourea derivative ligands and their $\mathrm{Ni}^{2+}$ and $\mathrm{Cu}^{2+}$ complexes have been synthesized. The compounds were screened for their in vitro anti-bacterial activity using Gram-positive bacteria (two different standard strains of Staphylococcus aureus, Staphylococcus epidermidis, Enterococcus faecalis, Streptococcus pyogenes, Bacillus cereus) and Gram-negative bacteria (Esherichia coli, Pseudomonas aeruginosa, Enterobacter cloacae, Proteus vulgaris, Enterobacter aerogenes) and in vitro anti-yeast activity (Candida albicans, Candida krusei, Candida glabrata, Candida tropicalis, Candida parapsilosis). The minimum inhibitory concentration was determined for all ligands and their complexes. In vitro anti-yeast activity of both ligands and their metal complexes is greater than their in vitro anti-bacterial activity. The effect of the structure of the investigated compounds on the antimicrobial activity is discussed.
\end{abstract}

Keywords: Thiourea derivatives; Complexes; Antibacterial activity; Antifungal activity; In vitro studies; Lipophilicity. 


\section{Introduction}

Industrial production and the use of $\mathrm{Fe}, \mathrm{Co}, \mathrm{Cu}, \mathrm{Ni}, \mathrm{Zn}, \mathrm{Cd}$, and $\mathrm{Pb}$ elements can cause environmental pollution. On the other hand, some of these metals are present in trace amounts as essential elements for biological systems and these metal ions also play an important role in bioinorganic chemistry. In order to understand the role of these metal ions in biological systems, structural studies of the biological compounds and their metal complexes are extremely important.

Compounds containing carbonyl and thiocarbonyl groups occupy an important position among organic reagents as potential donor ligands for transition metal ions [1-7]. Among these thiourea derivatives are potentially very versatile ligands, able to coordinate to a range of metal centres as neutral ligands, monoanions or dianions [1-12]. The oxygen, nitrogen and sulfur donor atoms of thiourea derivatives provide a multitude of bonding possibilities. Both the ligands and their metal complexes display a wide range of biological activity including antibacterial, antifungal, antitubercular, antithroid, antihelmintic, rodenticidal, insecticidal, herbicidal, and plant-growth regulator properties [13-17].

In view of this, our team focused on the synthesis, characterization, crystal structure, thermal behavior and antimicrobial activity of new thiourea derivatives [1-7, 18-25]. Following our examination of the antimicrobial activity of thiourea derivative ligands and their metal complexes, we now report on the anti-bacterial and anti-yeast activity of five thiourea derivative ligands: $(\mathrm{N}$ (diethylcarbamothioyl)cyclohexanecarboxamide $\left[\mathrm{L}^{1}\right], \quad N$-(di-n-propylcarbamothioyl)cyclohexane carboxamide $\left[\mathrm{L}^{2}\right]$ di-n-butylcarbamothioyl)cyclohexanecarboxamide $\left[\mathrm{L}^{3}\right], N$-(diphenylcarbamothioyl) cyclohexanecarboxamide $\left[\mathrm{L}^{4}\right], N$-(morpholine-4-carbonothioyl)cyclohexanecarboxamide $\left[\mathrm{L}^{5}\right]$ ) and their $\mathrm{Ni}^{2+}$ and $\mathrm{Cu}^{2+}$ metal complexes against standard bacterial (two different standard strains of Staphylococcus aureus, Staphylococcus epidermidis, Enterococcus faecalis, Streptococcus pyogenes, Bacillus cereus, Esherichia coli, Pseudomonas aeruginosa, Enterobacter cloacae, Proteus vulgaris, Enterobacter aerogenes) and yeast strains (Candida albicans, Candida krusei, Candida glabrata, Candida tropicalis, Candida parapsilosis).

\section{Results and Discussion}

The syntheses (Scheme 1) involve the reaction of a cyclohexanecarbonyl chloride with potassium thiocyanate in acetone, followed by condensation of the resulting cyclohexanecarbonyl isothiocyanate with an appropriate secondary amine (diethylamine, di- $n$-propylamine, di- $n$-butylamine, diphenylamine ormorpholine). The ligands were purified by re-crystallization from an ethanoldichloromethane mixture $(1: 2)$. The reaction of the ligands with metallic salts at room temperature with ethanol as solvent yielded the related metal complexes.

In the light of interesting antimicrobial activities of the coordination complexes, the thiourea derivative ligands and their $\mathrm{Ni}^{2+}$ and $\mathrm{Cu}^{2+}$ metal complexes were screened for antibacterial and antifungal activity against $S$. aureus, $S$. epidermidis, E. faecalis, S. pyogenes, B. cereus, B. cereus, E. coli, P. aeruginosa, E. cloacae, P. vulgaris, E. aerogenes, C. albicans, C. krusei, C. glabrata, C. tropicalis, C. parapsilosis by the broth microdilution procedure. The Gram positive anti-bacterial agent, amikacin, the Gram negative anti-bacterial agent, gentamycin, and the anti-fungal agent, nystatin, were used as controls. The in vitro antimicrobial properties against a number of Gram 
positive and Gram negative bacteria, and yeasts of both ligands and their metal complexes are presented in Tables 1-3, respectively.

Scheme 1. Synthesis of the compounds.

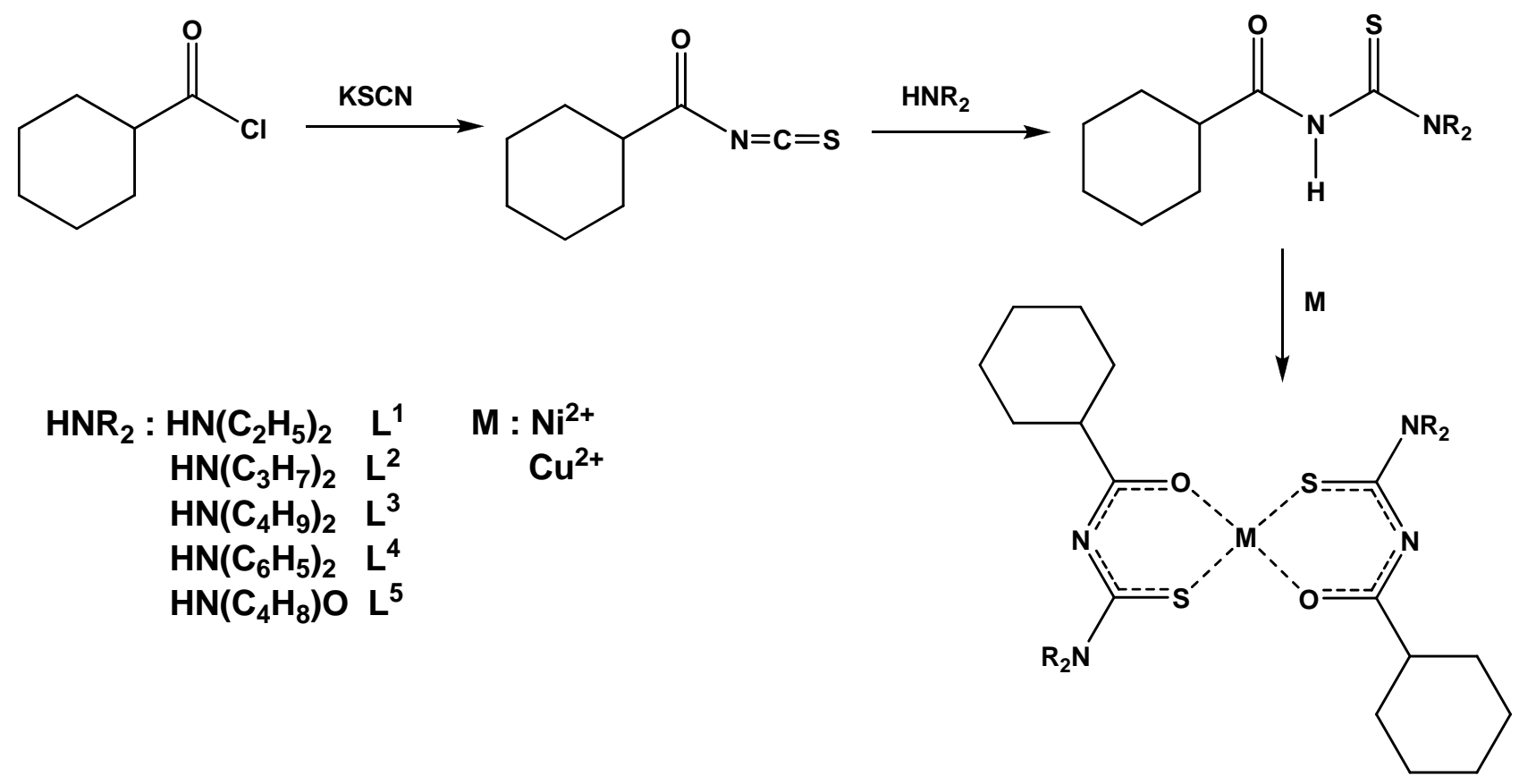

Table 1. MIC values $\left(\mu \mathrm{g} / \mathrm{cm}^{3}\right)$ of the compounds against the tested Gram positive bacteria.

\begin{tabular}{|c|c|c|c|c|c|c|}
\hline Compound & $\begin{array}{c}\text { S. aureus } \\
\text { (ATCC } \\
\text { 25923) }\end{array}$ & $\begin{array}{c}\text { S. aureus } \\
\text { (ATCC } \\
\text { 29213) }\end{array}$ & $\begin{array}{c}\text { S. epidermidis } \\
\text { (ATCC } \\
\text { 12228) }\end{array}$ & $\begin{array}{c}\text { E. faecalis } \\
\text { (ATCC } \\
\text { 29212) }\end{array}$ & $\begin{array}{c}\text { S. pyogenes } \\
\text { (Clinical } \\
\text { isolate) }\end{array}$ & $\begin{array}{c}\text { B. cereus } \\
\text { (Clinical } \\
\text { isolate) }\end{array}$ \\
\hline$L^{1}$ & 200 & 200 & 100 & 400 & 200 & 200 \\
\hline $\mathbf{L}^{2}$ & 400 & 200 & 200 & 200 & 200 & 100 \\
\hline $\mathbf{L}^{3}$ & 200 & 400 & 200 & 200 & 400 & 200 \\
\hline$L^{4}$ & 100 & 100 & 100 & 100 & 200 & 100 \\
\hline $\mathbf{L}^{5}$ & 400 & 200 & 100 & 100 & 200 & 200 \\
\hline $\mathrm{NiL}^{1}{ }_{2}$ & 200 & 200 & 200 & 200 & 200 & 200 \\
\hline $\mathrm{NiL}_{2}^{2}$ & 200 & 200 & 200 & 200 & 100 & 200 \\
\hline $\mathrm{NiL}_{2}{ }_{2}$ & 200 & 400 & 100 & 200 & 100 & 200 \\
\hline $\mathrm{NiL}_{2}^{4}$ & 400 & 400 & 100 & 200 & 100 & 100 \\
\hline $\mathrm{NiL}_{2}^{5}$ & 200 & 200 & 200 & 400 & 200 & 100 \\
\hline $\mathrm{CuL}^{1}{ }_{2}$ & 100 & 200 & 100 & 200 & 400 & 100 \\
\hline $\mathrm{CuL}_{2}{ }_{2}^{2}$ & 100 & 200 & 200 & 200 & 400 & 100 \\
\hline $\mathrm{CuL}_{2}^{3}$ & 200 & 400 & 200 & 200 & 400 & 200 \\
\hline $\mathrm{CuL}_{2}^{4}$ & 200 & 200 & 200 & 400 & 400 & 200 \\
\hline $\mathrm{CuL}_{2}^{5}$ & 50 & 100 & 100 & 200 & 200 & 100 \\
\hline Amikacin & 2 & 2 & 0.5 & 4 & 1 & 2 \\
\hline
\end{tabular}


Table 2. MIC values $\left(\mu \mathrm{g} / \mathrm{cm}^{3}\right)$ of the compounds against the tested Gram negative bacteria.

\begin{tabular}{|c|c|c|c|c|c|}
\hline Compound & $\begin{array}{c}\text { E. coli } \\
\text { (ATCC 25922) }\end{array}$ & $\begin{array}{c}\text { P. aeruginosa } \\
\text { (ATCC 27853) }\end{array}$ & $\begin{array}{c}\text { E. cloacae } \\
\text { (ATCC 13047) }\end{array}$ & $\begin{array}{c}\text { P. vulgaris } \\
\text { (ATCC 13315) }\end{array}$ & $\begin{array}{c}\text { E. aerogenes } \\
\text { (Clinical isolate) }\end{array}$ \\
\hline$L^{1}$ & 400 & 400 & 400 & 200 & 200 \\
\hline $\mathbf{L}^{2}$ & 200 & 400 & 200 & 200 & 400 \\
\hline $\mathbf{L}^{3}$ & 200 & 400 & 200 & 200 & 200 \\
\hline $\mathbf{L}^{4}$ & 200 & 400 & 200 & 200 & 400 \\
\hline $\mathbf{L}^{5}$ & 200 & 400 & 400 & 200 & 400 \\
\hline $\mathrm{NiL}_{2}{ }_{2}$ & 200 & 400 & 200 & 200 & 400 \\
\hline $\mathrm{NiL}_{2}^{2}$ & 200 & 400 & 200 & 200 & 200 \\
\hline $\mathrm{NiL}_{2}^{3}$ & 400 & 400 & 400 & 200 & 400 \\
\hline $\mathrm{NiL}_{2}^{4}$ & 400 & 400 & 400 & 400 & 200 \\
\hline $\mathrm{NiL}_{2}^{5}$ & 200 & 400 & 400 & 400 & 400 \\
\hline $\mathrm{CuL}^{1}{ }_{2}$ & 200 & 400 & 400 & 400 & 200 \\
\hline $\mathrm{CuL}_{2}{ }_{2}$ & 400 & 400 & 200 & 200 & 200 \\
\hline $\mathrm{CuL}_{2}^{3}$ & 400 & 400 & 200 & 100 & 400 \\
\hline $\mathrm{CuL}_{2}{ }_{2}$ & 400 & 400 & 400 & 200 & 400 \\
\hline $\mathrm{CuL}_{2}^{5}$ & 200 & 400 & 400 & 400 & 200 \\
\hline Gentamycin & 0.5 & 1 & 2 & 2 & 0.5 \\
\hline
\end{tabular}

Table 3. MIC values $\left(\mu \mathrm{g} / \mathrm{cm}^{3}\right)$ of the compounds against the tested fungi.

\begin{tabular}{|c|c|c|c|c|c|}
\hline Compound & $\begin{array}{c}\text { C. albicans } \\
\text { (ATCC 90028) }\end{array}$ & $\begin{array}{c}\text { C. krusei } \\
\text { (ATCC 6258) }\end{array}$ & $\begin{array}{c}\text { C. glabrata } \\
\text { (ATCC 32554) }\end{array}$ & $\begin{array}{c}\text { C. tropicalis } \\
\text { (ATCC 20336) }\end{array}$ & $\begin{array}{l}\text { C. parapsilosis } \\
\text { (Clinical isolate) }\end{array}$ \\
\hline$L^{1}$ & 50 & 50 & 50 & 50 & 50 \\
\hline $\mathbf{L}^{2}$ & 50 & 50 & 25 & 25 & 100 \\
\hline $\mathbf{L}^{3}$ & 100 & 100 & 25 & 25 & 50 \\
\hline$L^{4}$ & 25 & 50 & 50 & 50 & 50 \\
\hline $\mathbf{L}^{5}$ & 50 & 50 & 50 & 50 & 50 \\
\hline $\mathrm{NiL}_{2}{ }_{2}$ & 25 & 50 & 50 & 100 & 25 \\
\hline $\mathrm{NiL}_{2}^{2}$ & 25 & 50 & 25 & 50 & 50 \\
\hline $\mathrm{NiL}_{2}^{3}$ & 100 & 100 & 50 & 100 & 50 \\
\hline $\mathrm{NiL}_{2}^{4}$ & 50 & 25 & 25 & 50 & 100 \\
\hline $\mathrm{NiL}_{2}^{5}$ & 50 & 50 & 50 & 50 & 50 \\
\hline $\mathrm{CuL}^{1}{ }_{2}$ & 25 & 50 & 25 & 50 & 50 \\
\hline $\mathrm{CuL}_{2}^{2}$ & 25 & 50 & 25 & 25 & 25 \\
\hline $\mathrm{CuL}_{2}^{3}$ & 25 & 50 & 50 & 50 & 50 \\
\hline $\mathrm{CuL}_{2}^{4}$ & 50 & 25 & 25 & 25 & 50 \\
\hline $\mathrm{CuL}_{2}^{5}$ & 25 & 25 & 25 & 25 & 25 \\
\hline Nystatin & 1 & 0.5 & 2 & 4 & 4 \\
\hline
\end{tabular}


All compounds inhibited the growth of bacteria with MIC values ranging between 50 and 400 $\mu \mathrm{g} / \mathrm{cm}^{3}$ and showed anti-yeast activity with MICs between 25 and $100 \mu \mathrm{g} / \mathrm{cm}^{3}$. According to the antimicrobial studies, all compounds showed such activity, albeit lower than their anti-yeast efficacy. This difference may be due to the differences between the cell structures of bacteria and yeast. While the cell walls of fungi contain chitin, the cell walls of bacteria contain murein [17]. In addition, fungi contain ergosterol in their cell membranes instead of the cholesterol found in the cell membranes of animals [4, 26].

$\mathrm{CuL}_{2}^{5}$ show good activity against C. albicans, C. krusei, C. glabrata, and C. tropicalis. $\mathrm{NiL}_{2}^{3}$ showed low activity against C. albicans, C. krusei, and C. tropicalis. When all the anti-yeast MIC values are compared, twelve of fifteen compounds show good activity against $C$. glabrata and ten of fifteen compounds show low activity against C. parapsilosis. According to the anti-bacterial studies, the efficacy against Gram positive bacteria is higher than against Gram negative bacteria. Eleven of fifteen compounds show good activity against $S$. epidermidis and eight of fifteen compounds show low activity against $S$. pyogenes. In addition, $\mathrm{L}^{4}$ showed high activity against all Gram positive bacteria.

The investigated compound antimicrobial activity values in this research were lower than that reported for other thiourea derivatives $[4,6,17,19]$. The main difference in the thiourea derivatives reported in this paper is the presence of the cyclohexyl moiety. The other derivatives included substituted benzyl groups. Lipophilicity, which correlates well with the bioactivity of chemicals, is a very important molecular descriptor and different lipophilic behaviour of compounds plays an important role in their biological activity mechanisms. The $n$-octanol/water partition coefficient (log $\left.P_{\text {ow }}\right)$ is widely used as a general measure of lipophilicity. Compounds with benzyl groups have relatively higher $\log P_{\text {ow }}$ values and hence show more lipophilic character as compared to the compounds with cyclohexyl groups [27].

It is interesting to note that the investigated compounds with cyclohexane group show lower antimicrobial activity. This behavior can be attributed to the fact that due to their low lipophilicity, these compounds do not penetrate into the microorganisms as easily as the thiourea derivatives with benzyl group do. Similar behavior is observed in the anti-yeast activity MIC values for $\mathrm{CuL}_{2}^{5}$ and $\mathrm{NiL}_{2}^{5}$. The compound with a morpholine ring, which has the $\log P_{\text {ow }}$ value of 2.55 , show higher anti-microbial activity than the other investigated compounds due probability to their higher lipophilic character.

The results show that the copper complexes are more active against the tested yeast as compared to the nickel complexes. The increase in antifungal activity of the copper complexes can be ascribed to the effect of the copper metal ion on the normal cell process. The complexation reaction reduces the polarity of the metal ion by the partial sharing of metal ion's positive charge with donor groups and electron delocalization over the chelate ring. Thus, the lipophilic character of the central metal atom is enhanced which results in a higher capability to penetrate the microorganisms through the lipid layer of the cell membrane. Although MIC values for some compounds are good, unfortunately, the antiyeast and anti-bacterial activity values of all tested compounds are lower than the reference compounds, thus these compounds cannot be suggested for clinical use. 


\section{Experimental}

Synthesis

The ligands were prepared by a procedure similar to that reported in the literature (Scheme 1) [3]. A solution of cyclohexanecarbonyl chloride $(0.005 \mathrm{~mole})$ in acetone $(30 \mathrm{~mL})$ was added dropwise to a suspension of potassium thiocyanate $(0.005 \mathrm{~mole})$ in acetone $(30 \mathrm{~mL})$. The reaction mixture was heated $\left(50{ }^{\circ} \mathrm{C}\right)$ under reflux for $30 \mathrm{~min}$, and then cooled to room temperature. A solution of secondary amine $(0.005$ mole $)$ in acetone $(30 \mathrm{~mL})$ was added and the resulting mixture was stirred for $2 \mathrm{~h}$. Hydrochloric acid $(0.1 \mathrm{~N}, 100 \mathrm{~mL})$ was added and the solution filtered. The solid product was washed with water and purified by recrystallization from an ethanol-dichloromethane mixture (1:2). Metallic complexes were prepared according to the method described in the literature [3]. A solution of the metallic acetate $(0.01 \mathrm{~mole})$ in ethanol $(30 \mathrm{~mL})$ was added dropwise to a solution of the ligand in a $1: 2$ ratio for all metal with a small excess of ligand in ethanol $(30 \mathrm{~mL})$ at room temperature and the resulting mixture was stirred for $30 \mathrm{~min}$. The solid complexes were filtered and re-crystallized from a 1:2 ethanol-dichloromethane mixture.

\section{Antimicrobial activity}

The compounds were screened for their in vitro anti-bacterial and anti-yeast activities. Antimicrobial activities of both ligands and complexes were determined by the broth microdilution procedures and principles of the Clinical and Laboratory Standards Institute (CLSI) [28, 29]. Minimal inhibitory concentrations for each compound were investigated against standard bacterial strains; $S$. aureus (ATCC 25923), S. aureus (ATCC 29213), S. epidermidis (ATCC 12228), E. faecalis (ATCC 29212), S. pyogenes (clinical isolate), B. cereus (clinical isolate), E. coli (ATCC 25922), P. aeruginosa (ATCC 27853), E. cloacae (ATCC 13047), P. vulgaris (ATCC 13315), E. aerogenes (clinical isolate), and yeast-like fungi; C. albicans (ATCC 90028), C. krusei (ATCC 6258), C. glabrata (ATCC 32554), C. tropicalis (ATCC 20336), C. parapsilosis (clinical isolate) obtained from the Refik Saydam Hifzissihha Institute, Ankara, Turkey, Microbiology Culture Collection of Inonu University, Malatya, Turkey, and Department of Microbiology, Faculty of Medicine, Ege University, İzmir, Turkey. Bacterial and fungal colonies of the test organisms were suspended directly into a small volume of $0.9 \%$ saline and further diluted until turbidity matched the Mc Farland standard no: 0.5 Petri dishes containing Mueller-Hinton agar for bacteria and Sabouraud Dextrose agar for fungi were impregnated with these microbial suspensions. The stock solutions were prepared in dimethyl sulfoxide (DMSO), which had no effect on the microorganisms in the concentrations studied. All of the dilutions were done with distillated water. The concentrations of tested compounds were 400, 200, $100,50,25,12.5,6.25,3.125 \mu \mathrm{g} / \mathrm{cm}^{3}$. DMSO was used as negative control. Amikacin, gentamycin, and nystatin were used as reference drugs for Gram positive anti-bacterial activity, Gram negative anti-bacterial activity and antifungal activity, respectively. All the inoculated plates were incubated at $35{ }^{\circ} \mathrm{C}$ and results were evaluated after $16-20 \mathrm{~h}$ for bacteria and $48 \mathrm{~h}$ for fungi. The lowest concentration of the compounds that prevented visible growth was considered to be minimal inhibitor concentrations (MICs). 


\section{Acknowledgements}

Support for this research was provided by grant P20 MD001089 and S06 GM078246-01 from the USA National Institution of Health, NCMHD, and Department of Health and Human Services.

\section{References}

1. Arslan, H.; Kulcu, N.; Florke, U. Synthesis and characterization of copper(II), nickel(II) and cobalt(II) complexes with novel thiourea derivatives. Transit. Metal Chem. 2003, 28, 816-819.

2. Mansuroglu, D.S.; Arslan, H.; Florke, U.; Kulcu, N. Synthesis and characterization of nickel and copper complexes with 2,2-diphenyl-N-(alkyl(aryl)carbamothioyl)acetamide: The crystal structures of HL1 and cis-[Ni(L-1)(2)]. J. Coord. Chem. 2008, 61, 3134-3146.

3. Ozer, C.K.; Arslan, H.; VanDerveer, D.; Binzet, G. Synthesis and characterization of N(alky(aryl)carbamothioyl)cyclohexanecarboxamide derivatives and their $\mathrm{Ni}(\mathrm{II})$ and $\mathrm{Cu}(\mathrm{II})$ complexes. J. Coord. Chem. 2009, 62, 266-276.

4. Binzet, G.; Arslan, H.; Florke, U.; Kulcu, N.; Duran, N. Synthesis, characterization and antimicrobial activities of transition metal complexes of N,N-dialkyl-N'-(2-chlorobenzoyl)thiourea derivatives. J. Coord. Chem. 2006, 59, 1395-1406.

5. Ugur, D.; Arslan, H.; Kulcu, N. Synthesis, characterization and thermal behavior of 1,1-dialkyl3-(4-(3,3-dialkylthioureidocarbonyl)benzoyl)thiourea and its $\mathrm{Cu}(\mathrm{II}), \mathrm{Ni}(\mathrm{II})$, and $\mathrm{Co}(\mathrm{II})$ complexes. Russ. J. Coord. Chem. 2006, 32, 669-675.

6. Emen, M.F.; Arslan, H.; Kulcu, N.; Florke, U.; Duran, N. Synthesis, characterization and antimicrobial activities of some metal complexes with $\mathrm{N}$ '-(2-chloro-benzoyl)thiourea ligands: The crystal structure of fac-[CoL3] and cis-[PdL2]. Pol. J. Chem. 2005, 79, 1615-1626.

7. Arslan, H.; Florke, U.; Kulcu, N.; Emen, M.F. Crystal structure and thermal behaviour of copper(II) and zinc(II) complexes with N-pyrrolidine-N'-(2-chloro-benzoyl)thiourea. J. Coord. Chem. 2006, 59, 223-228.

8. Henderson, W.; Nicholson, B.K.; Dinger, M.B.; Bennett, R.L. Thiourea monoanion and dianion complexes of rhodium(III) and ruthenium(II). Inorg. Chim. Acta 2002, 338, 210-218.

9. Sacht, C.; Datt, M.S.; Otto, S.; Roodt, A. Synthesis, characterisation and coordination chemistry of novel chiral N,N-dialkyl-N-menthyloxycarbonylthioureas. Crystal and molecular structures of N,N-diethyl-N-(-)-(3R)-menthyloxycarbonylthiourea and cis-(S,S)-[Pt(L)Cl(DMSO)] [where HL $=\mathrm{N}-(+)-(3 \mathrm{R})$-menthyloxycarbonyl-N'-morpholinothiourea or N-benzoyl-N',N'-diethylthiourea]. J. Chem. Soc., Dalton Trans. 2000, 24, 4579-4586.

10. Lipowska, M.; Hayes, B.L.; Hansen, L.; Taylor, A.; Marzilli, L.G. Rhenium(V) oxo complexes of novel N2S2 dithiourea (DTU) chelate ligands: Synthesis and structural characterization. Inorg. Chem. 1996, 35, 4227-4231.

11. Zuckerman, R.L.; Bergman, R.G. Structural factors that influence the course of overall [2+2] cycloaddition reactions between imidozirconocene complexes and heterocumulenes. Organometallics 2000, 19, 4795-4809.

12. Henderson, W.; Kemmitt, R.D.W.; Mason, S.; Moore, M.R.; Fawcett, J.; Russell, D.R. Thiadiazatrimethylenemethane and N,N',P-Triphenylphosphonothioic Diamide Complexes of 
Platinum(Ii). J. Chem. Soc., Dalton Trans. 1992, 1, 59-66.

13. Yuan, Y.F.; Wang, J.T.; Gimeno, M.C.; Laguna, A.; Jones, P.G. Synthesis and characterisation of copper complexes with N-ferrocenoyl-N '(alkyl)thioureas. Inorg. Chim. Acta 2001, 324, 309317.

14. Zhang, Y.M.; Wei, T.B.; Xian, L.; Gao, L. M. An efficient synthesis of polymethylene-bis-aroyl thiourea derivatives under the condition of phase-transfer catalysis. Phosphorus Sulfur Silicon Relat. Elem. 2004, 179, 2007-2013.

15. Zhang, Y.M.; Wei, T.B.; Wang, X.C.; Yang, S.Y. Synthesis and biological activity of N-aroyl-N '-carboxyalkyl thiourea derivatives. Indian J. Chem. Sect B 1998, 37, 604-606.

16. Zhou, W. Q.; Li, B. L.; Zhu, L. M.; Ding, J. G.; Yong, Z.; Lu, L.; Yang, X. J., Structural and spectral studies on N-(4-chloro)benzoyl-N'-(4-tolyl)thiourea. J. Mol. Struct. 2004, 690, 145-150.

17. Eweis, M.; Elkholy, S.S.; Elsabee, M.Z. Antifungal efficacy of chitosan and its thiourea derivatives upon the growth of some sugar-beet pathogens. Int. J. Biol. Macromol. 2006, 38, 1-8.

18. Arslan, H.; Florke, U.; Kulcu, N. N'-(4-Chlorobenzoyl)-N,N-diphenylthiourea. Acta Cryst. E 2003, 59, O641-O642.

19. Arslan, H.; Florke, U.; Kulcu, N. Synthesis, characterization, and crystal structure of 1-(4chloro-benzoyl)-3-naphthalen-1-yl-thiourea. J. Chem. Crystallogr. 2003, 33, 919-924.

20. Arslan, H.; Florke, U.; Kulcu, N. The crystal and molecular structure of 1-(biphenyl-4carbonyl)-3-p-tolyl-thiourea. Acta Chim. Slov. 2004, 51, 787-792.

21. Arslan, H.; Kulcu, N.; Florke, U. Normal coordinate analysis and crystal structure of N,Ndimethyl-N'-(2-chloro-benzoyl)thiourea. Spectrochim. Acta, Part A 2006, 64, 1065-1071.

22. Arslan, H.; Florke, U.; Kulcu, N. Theoretical studies of molecular structure and vibrational spectra of O-ethyl benzoylthiocarbamate. Spectrochim. Acta, Part A 2007, 67, 936-943.

23. Arslan, H.; Ozpozan, N.; Ozpozan, T. Thermal studies of p-toluidino-p-chlorophenylglyoxime and of some corresponding $\mathrm{Ni}(\mathrm{II}), \mathrm{Cu}(\mathrm{II})$ and $\mathrm{Co}(\mathrm{II})$ complexes. Thermochim. Acta 1999, 329, 57-65.

24. Avsar, G.; Kulcu, N.; Arslan, H. Thermal behaviour of copper(II), nickel(II), cobalt(II) and palladium(II) complexes of N,N-dimethyl-N '-benzoylthiourea. Turk. J. Chem. 2002, 26, 607615.

25. Ugur, D.; Florke, U.; Kulcu, N.; Arslan, H. 3-[4-(3,3-diethylthioureidocarbonoyl)-benzoyl]-1,1diethylthiourea. Acta Cryst. E 2003, 59, O1345-O1346.

26. Fleet, G.H. Composition and Structure of Yeast Cell Walls: Current Topics in Medical Mycology, Springer-Verlag: New York, USA, 1985; Vol. 1.

27. Hoey, A.J.; Jackson, C.M.; Pegg, G.G.; Sillence, M.N. Characteristics of cyanopindolol analogues active at the beta(3)-adrenoceptor in rat ileum. Br. J. Pharmacol. 1996, 119, 564-568.

28. National Committee for Clinical Laboratory Standards. Methods for dilution antimicrobial susceptibility tests for bacteria that grow aerobically, Approved Standard M7-A4. NCCLS: Viallanova, PA, USA, 1997.

29. National Committee for Clinical Laboratory Standards. Reference method for broth dilution antifungal susceptibility testing of yeasts, Approved Standard M27-A2. NCCLS: Wayne, PA, USA, 2002. 
Sample Availability: Samples of the compounds are available from the authors.

(C) 2009 by the authors; licensee Molecular Diversity Preservation International, Basel, Switzerland. This article is an open-access article distributed under the terms and conditions of the Creative Commons Attribution license (http://creativecommons.org/licenses/by/3.0/). 